\title{
ANALISIS PENGARUH FAKTOR-FAKTOR BASE LENDING RATE TERHADAP RETURN ON EQUITY PADA KSP. MADANI NTB
}

\author{
I Nengah Arsana ${ }^{1}$ \\ Irianto ${ }^{2}$ \\ Baiq Kisnawati ${ }^{3}$ \\ ${ }^{123}$ Sekolah Tinggi Ilmu Ekonomi AMM Mataram
}

\begin{abstract}
This study entitled "Analysis of the Effects of Base Lending Rate Factors on Return On Equity On KSP. Madani NTB ". This study aims to measure the effect of partial and simultaneous variables factors Base Lending Rate (Cost of Laonable Fund, Overhead Cost, Risk Cost, Tax Rate) on Return On Equity on KSP. Madani NTB and analyze the variable Cost of Laonable Fund, Overhead Cost, Risk Cost, Tax Rate is the most dominant and significantly affect the Return On Equity on KSP. Madani NTB.

The type of research used in this study is associative research. Data collection techniques conducted in this study are observation, interview and documentation. The type of data used is quantitative data. The procedure of data analysis using multiple regression model analysis.

The results of this study indicate that the Cost of Laonable Fund, Overhead Cost, Risk Cost, Tax Rate is not entirely partially have a significant effect on Return on Equity on KSP.Madani NTB, caused by 1 (one) variable Tax Rate partially has no influence significant to the Return on Equity variable (Y), and all independent variables (Cost of Laonable Fund, Overhead Cost, Risk Cost, Tax Rate) simultaneously give a significant influence on the Return on Equity variable (Y). In addition, Risk Cost variable has the most dominant influence on Return on Equity in KSP.Madani NTB.
\end{abstract}

Keywords: Base Lending Rate Factor, Return on Equity. 


\section{PENDAHULUAN}

\section{Latar Belakang}

Setiap kegiatan usaha yang menginginkan usahanya meningkat dan berkembang, maka salah satu faktor penunjangnya adalah ketersediaan sumber dana untuk membiayai kegiatan operasional dan kegiatan investasi. Dana tersebut didapat dari berbagai sumber, di antaranya bersumber dari para pemilik perusahaan, pinjaman dari bank, atau dari sumber-sumber lainnya. Demikian juga dengan koperasi, khususnya koperasi simpan pinjam dalam melakukan kegiatan usaha sebagian besar sumber dananya berasal dari para anggota dalam bentuk simpanan pokok, simpanan wajib, simpanan sukarela, donasi para anggota, serta pinjaman-pinjaman dari dari pihak lain atau dari perbankan.

Koperasi di dalam melakukan kegiatan usaha tidak bisa terlepas dari peran serta anggotanya, dalam hal ini anggota satu sisi sebagai pemilik dan sisi lain sebagai pengguna jasa. Oleh karenanya koperasi harus meningkatkan pelayanannya kepada anggota koperasi tersebut, koperasi harus mampu mengelola sumber dana yang berhasil dihimpun, kemudian disalurkan kembali kepada anggota dalam bentuk kredit, yang selanjutnya koperasi memperoleh imbalan atas kredit yang diberikan yang akan digunakan untuk membayar bunga atas sumber dana yang diperoleh koperasi.

Pada saat ini persaingan antar lembaga keuangan baik bank maupun non bank semakin ketat, demikian halnya dengan koperasi simpan pinjam dalam menarik masyarakat untuk mau menjadi anggota yang nantinya memanfaatkan jasa koperasi dalam menyimpan maupun meminjam sangatlah ketat. Salah satu faktor penting yang perlu diperhatikan untuk bisa melayani anggotanya dengan baik adalah dalam hal pemberian jasa simpanan maupun jasa pinjaman.

Besarnya jasa simpanan diberikan kepada anggota penyimpan akan berpengaruh terhadap besarnya jasa pinjaman yang dibebankan kepada anggota peminjam. Disamping itu koperasi harus memperhatikan pengalokasian sumber dana dihimpun ke dalam aktiva-aktiva produktif yang menghasilkan pendapatan bagi koperasi, atau dialokasikan dalam bentuk pemberian pinjaman kepada anggota dengan tingkat bunga yang wajar.Tingkat bunga yang wajar akan berpeluang untuk meningkatkan pemberian kredit kepada anggota dan akan berpeluang meningkatkan keuntungan.

Penentuan tingkat bunga kredit (base lending rate) harus memperhatikan berbagai faktor, diantaranya faktor komposisi sumber dana yang berhasil dihimpun yang sebagian digunakan untuk cadangan likuiditas dan sebagian untuk dialokasikan dalam pemberian kredit. Komposisi sumber dana mempengaruhi biaya dana, semakin besar sumber dana yang dialokasikan dalam bentuk cadangan likuiditas, semakin kecil jumlah dana 
yang dapat ditempatkan, maka semakin besar biaya dana atau harga sumber dana tersebut. Disamping biaya bunga tersebut di atas, koperasi juga harus menanggung beban diluar bunga dalam proses penghimpunan dana dalam bentuk biaya tenaga kerja, biaya sewa kantor, dan lain-lain.

Faktor lain yang juga mempengaruhi tingkat bunga kredit adalah kualitas kredit yang diberikan kepada anggota, kualitas kredit yang banyak bermasalah akan berdampak pada risiko kredit dan risiko kredit akan menimbulkan biaya risiko kredit. Faktor lain yang mempengaruhi penentuan tingkat bunga adalah tingkat pajak dan tingkat keuntungan yang ingin diperoleh oleh koperasi.

Berdasarkan latar belakang di atas, maka penulis akan melakukan penelitian dengan judul Analisis Pengaruh Faktor-Faktor Base Lending Rate Terhadap Return On Equity Pada KSP. Madani NTB.

\section{Rumusan Masalah}

Berdasarkan latar belakang di atas, maka pokok permasalahannya dapat dirumuskan sebagai berikut :

1. Apakah ada pengaruh signifikan baik secara parsial dan simultan faktorfaktor Base Lending Rate terhadap Return On Equity pada KSP. Madani NTB ?

2. Dari variabel faktor-faktor Base Lending Rate manakah yang paling dominan dan signifikan yang mempengaruhi Return On Equity pada KSP. Madani NTB ?

\section{Batasan Masalah}

Agar pembahasan lebih fokus, maka permasalahan tersebut dibatasi oleh hal-hal berikut :

1. Penelitian dilakukan terhadap KSP. Madani NTB Tahun 2008-2017

2. Meneliti keterkaitan faktor-faktor Base Lending Rate (Cost of Laonable Fund/COLF, Overhead Cost/OHC, Risk Cost, Tax Rate) dengan Return on Equity pada KSP. Madani NTB mulai tahun 2008-2017

\section{Tujuan Penelitian}

Adapun tujuan penelitian ini adalah untuk mengetahui dan memahami hal-hal sebagai berikut :

1) Untuk mengukur pengaruh secara parsial dan simultan variabel faktorfaktor Base Lending Rate (Cost of Laonable Fund/COLF, Overhead Cost/OHC, Risk Cost, Tax Rate) terhadap Return On Equity pada KSP. Madani NTB.

2) Untuk menganalisis variabel faktor-faktor Base Lending Rate (Cost of Laonable Fund/COLF, Overhead Cost/OHC, Risk Cost, Tax Rate) yang paling dominan dan signifikan mempengaruhi Return On Equity pada KSP. Madani NTB.

\section{Manfaat Penelitian}


Manfaat dari penelitian ini adalah agar hasil penelitian ini diharapkan dapat memberikan manfaat dan sumbangan pemikiran kepada pengurus, pengelola, dan anggota koperasi, serta masyarakat sebagai bahan pertimbangan dalam pengambilan keputusan untuk menyalurkan sumber dana yang diperoleh koperasi.

\section{TINJAUAN PUSTAKA}

\section{Pengertian Koperasi}

Koperasi merupakan badan usaha yang sekaligus sebagai gerakan ekonomi rakyat yang sudah lama dikenal di Indonesia yang merupakan suatu kumpulan dari orang-orang yang mempunyai tujuan yang sama. Pengertian Koperasi menurut Undang-Undang Nomor 25 Tahun 1992 Tentang Perkoperasian, "Koperasi adalah badan usaha yang beranggotakan orang-seorang atau badan hukum koperasi dengan melandaskan kegiatannya berdasarkan prinsip koperasi sekaligus sebagai gerakan ekonomi rakyat yang berdasar atas asas kekeluargaan".

\section{Jenis-Jenis Koperasi}

Salah satu tujuan pendirian koperasi didasarkan kepada kebutuhan dan kepentingan para anggotanya. "Masing-masing kelompok masyarakat yang mendirikan koperasi memiliki kepentingan atau tujuan yang berbeda, perbedaan kepentingan ini menyebabkan koperasi dibentuk dalam beberapa jenis sesuai dengan kebutuhan kelompok tersebut".(Kasmir, 2010 : 288)

Berdasarkan kegiatan usaha secara umum, koperasi dapat dikelompokkan menjadi :

1. Koperasi Konsumen, adalah koperasi yang usahanya memenuhi kebutuhan sehari-hari anggota koperasi.

2. Koperasi Produsen, adalah koperasi yang anggotanya menghasilkan produk yang kemudian dijual atau dipasarkan melalui koperasi.

3. Koperasi Simpan-Pinjam, adalah koperasi yang melayani kegiatan peminjaman dan penyimpanan uang para anggota. (Muljono, 2012:4)

\section{Kegiatan Usaha Koperasi Simpan Pinjam}

Menurut Peraturan Menteri Koperasi dan UKM Republik Indonesia Nomor 02/PER/M.KUKM/II/2017 kegiatan usaha simpan pinjam meliputi :

1. Menghimpun simpanan berjangka dan tabungan koperasi dari anggota, calon anggota, koperasi lain dan/atau anggotanya.

2. Memberikan pinjaman kepada anggota, calon anggota, koperasi lain dan/atau anggotanya; dan

3. Dalam kegiatan usaha simpan pinjam wajib mengelola keseimbangan sumber dana dan penyaluran pinjaman. 
Sejalan dengan kegiatan usaha koperasi simpan pinjam tersebut di atas, boleh dikatakan bahwa koperasi simpan pinjam adalah usaha pembiayaan, yaitu menghimpun dana dari para anggotanya yang kemudian menyalurkan kembali kepada para anggota yang membutuhkan dalam bentuk pinjaman. Kegiatan usaha simpan pinjam dilaksanakan dengan tata kelola yang baik, menerapkan prinsip kehati-hatian dan manajemen risiko, serta mematuhi peraturan yang terkait dengan pengelolaan usaha simpan pinjam

\section{Tujuan Koperasi Simpan Pinjam}

Tujuan Koperasi Simpan Pinjam adalah memberi manfaat kepada anggota (Muljono, 2012 : 5), antara lain :

1. Memberi kemudahan anggota untuk memperoleh modal usaha

2. Memberi keuntungan kepada anggota melalui Sisa Hasil Usaha (SHU)

3. Mengembangkan usaha anggota koperasi

4. Meniadakan praktek rentenir.

Memberikan kemudahan bagi anggota untuk memperoleh modal usaha, disini diharapkan koperasi dalam hal memberikan pinjaman harus dengan persyaratan yang relatif lebih mudah dibandingkan dengan lembaga keuangan lain, namun demikian kemudahan persyaratan peminjaman tersebut tidak harus menghilangkan kehati-hatian koperasi dalam menyalurkan pinjaman.

\section{Base Lending Rate}

Secara umum penentuan tingkat suku bunga kredit akan dipengaruhi oleh beberapa faktor (Taswan, 2010:325), yaitu sebagai berikut :

\section{a. Cost of Loanable Funds (COLF)}

Tingkat Cost of Loanable Funds dipengaruhi oleh struktur dana, komposisi dana, tingkat bunga dana (borrowing rate) dan reserve requirement. Semakin tinggi tingkat bunga dan reserve requirement, maka semakin tinggi cost of Loanable Funds dan akan terjadi sebaliknya, apabila borrowing rate dan reserve requirement turun. Cost of Loanable Funds yaitu ditempatkan yang dioperasionalkan (ditempatkan) untuk memperoleh pendapatan. Dana operasional adalah total dana yang dihimpun dikurangi dengan unloanable funds (dana yang tidak ditempatkan pada aktiva produktif untuk tujuan berjagajaga/cadangan). COLF dalam persentase dapat diformulasikan :

$\begin{array}{ll}\text { COLF }= & \text { Total Biaya Dana } \\ \text { - } & \text { Total Dana }- \text { Unloanable Fund }\end{array}$


b. Overhead Cost $(\mathrm{OHC})$

Biaya ini merupakan biaya selain bunga yang dikeluarkan dalam proses penghimpunan dana, misalnya : biaya tenaga kerja, biaya sewa kantor, biaya penyusutan, biaya transport, biaya promosi, dan biaya lainnya. Untuk mengalokasikan biaya overhead dapat digunakan rumus :

Total Biaya Proses Dana Selain Bunga

$\mathrm{OHC}=\quad$ -

c. Risk Cost (Bad Debt)

Total Dana

Biaya ini ditentukan dari besarnya cadangan penghapusan kredit, setelah cadangan penghapusan kredit dihitung berdasarkan data historis, maka risk cost dapat ditentukan dengan rumus :

Bad Debt

d. Spread

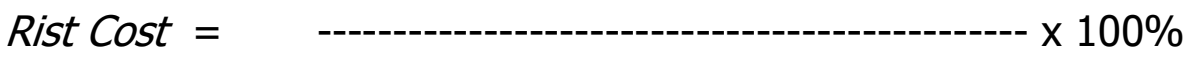

\section{Loanable Funds}

Spread merupakan margin yang diproyeksikan. Dalam perencanaan bunga kredit, spread merupakan perbandingan proyeksi spread terhadap baki debet atau loanable funds. Besarnya spread pada tingkat operasional sering dipengaruhi oleh kualitas jaminan kredit, jangka waktu kredit, dan reputasi debitur. Spread dapat ditentukan dengan rumus :

$$
\begin{aligned}
& \text { Tingkat Spread = } \quad \text { - } \\
& \text { Loanable Funds }
\end{aligned}
$$

e. Tingkat Pajak (Tax Rate)

Suku bunga kredit dapat ditetapkan tegantung dari besarnya pajak yang ditanggung atas penempatan dana pada kredit. Tax rate diperhitungkan dalam base lending rate yang besarnya tergantung dari proyeksi spread yang ditentukan. Secara singkat tingkat pajak dapat ditentukan dengan rumus :

$$
\begin{array}{ll}
\text { Tingkat Pajak }= & \text { Kewajiban Pajak } \\
\hdashline---------------------- & \text { Penempatan Dana Pada Kredit }
\end{array}
$$

\section{Return On Equity}

Rasio rentabilitas modal sendiri (Return On Equity) adalah SHU bagian anggota dibandingkan total modal sendiri. Yang perhitungannya ditetapkan berdasarkan Peraturan Deputi Bidang Pengawasan Kementerian Koperasi dan UKM Republik Indonesia No. 06/PER/DEP.6/IV/2016, sebagai sebagai berikut:

$$
\begin{array}{ll}
\text { Return on Equity }= & \text { SHU Bagian Anggota } \\
\hline--------- & \text { Total Modal Sendiri }
\end{array}
$$




\section{Kerangka Berfikir Penelitian}

Kerangka berfikir penelitian dapat dijabarkan pada Gambar 2.1 di bawah ini, sebagai berikut :

Gambar 1

Kerangka Pemikiran Teoretis

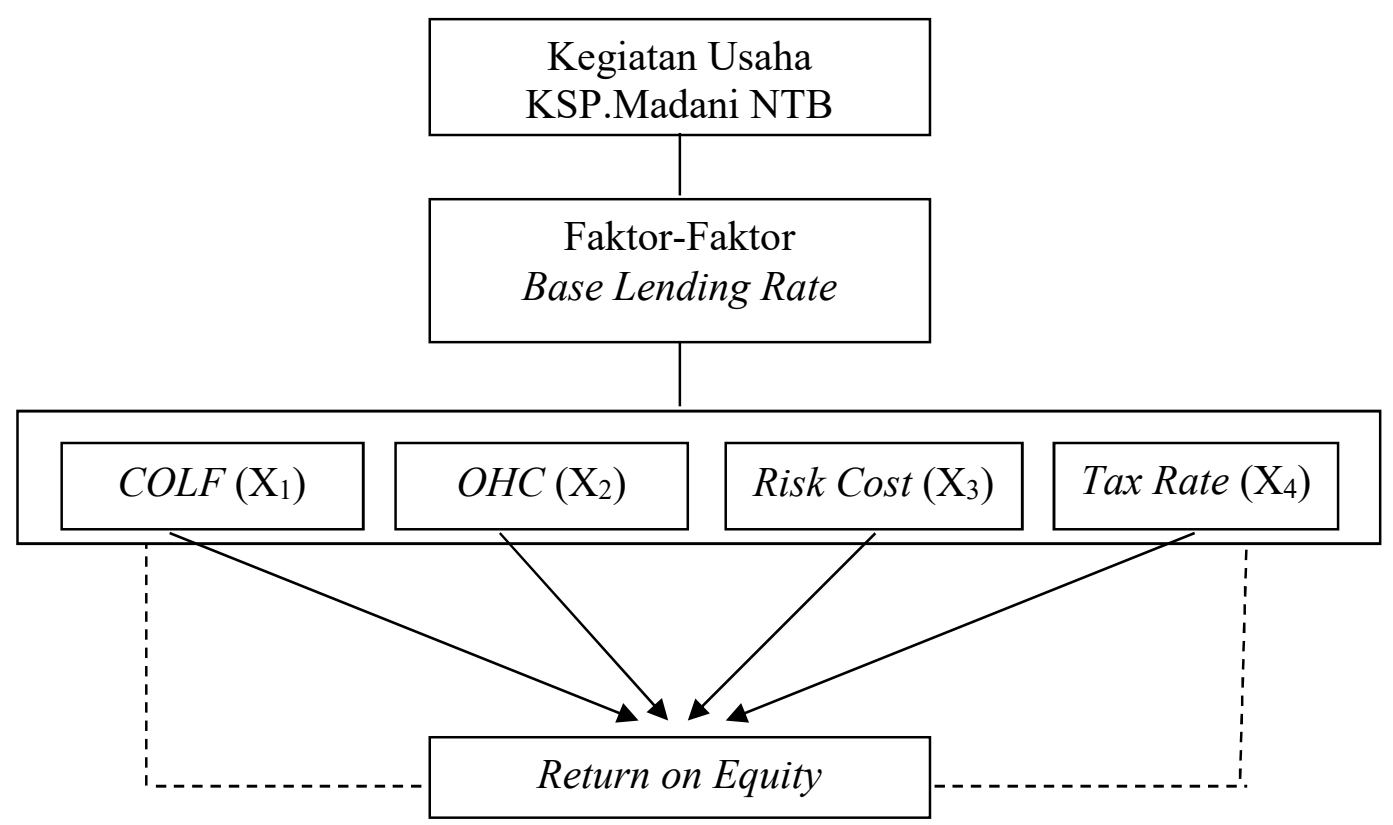

Kerangka pemikiran teoretis yang tergambar di atas, menunjukkan dari kegiatan usaha koperasi simpan pinjam, yang kegiatan utamanya adalah menarik dana dari anggota dan menyalurkan kembali kepada anggota, dalam kegiatan tersebut diharapkan sumber dana yang berhasil dihimpun mampu disalurakn kembali kepada anggota dengan tingkat bunga kredit yang terjangkau dan memperoleh tingkat keuntungan yang memadai. Faktor-faktor tingkat bunga kredit (Base Lending Rate) akan berpengaruh secara parsial dan simultan terhadap Return on Equity pada KSP.Madani NTB.

\section{METODE PENELITIAN}

\section{Jenis Penelitian}

Jenis penelitian yang digunakan dalam penelitian ini adalah penelitian asosiatif, yang bertujuan untuk mengetahui hubungan antara variabel faktor-faktor Base Lending Rate (Cost of Loanable Fund, Overhead Cost, Risk Rate, Tax Rate) dengan variabel Return on Equity/ROE yang menekankan pada data-data yang sudah ada diolah dengan metode statistika pada KSP.Madani NTB. 


\section{Lokasi Penelitian}

Penelitian ini dilakukan pada KSP. Madani NTB, yang beralamat di Jalan Raya Tanjung, Desa Medana, Kecamatan Tanjung, Kabupaten Lombok Utara.

\section{Teknik dan Alat Pengumpulan data Teknik Pengumpulan Data}

Adapun teknik pengumpulan data yang digunakan dalam penelitian ini adalah :

1) Obesrbvasi yaitu peneliti mengadakan pengamatan langsung di KSP. Madani NTB disertai dengan pencatatan secara sistematis terhadap hal-hal yang diselidiki guna memperoleh data yang diperlukan.

2) Wawancara, mengadakan tanya jawab dengan pihak-pihak yang berwenang memberikan informasi atau data yang berhubungan dengan obyek penelitian.

3) Dokumentasi, dengan cara mempelajari atau menyalin catatan atau dokumen yang berhubungan dengan data yang dikumpulkan dan untuk mendapatkan data yang diperlukan langkah-langkah, yakni dari perencanaan penelitian, pengumpulan, pengolahan dan penataan data, penyajian data dalam bentuk tabel, serta analisis dan interpretasi data.

\section{Alat Pengumpul Data}

Alat pengumpulan data dalam penelitian ini adalah berupa kuisioner yang ditujukan kepada pihak yang berwenang memberikan informasi, berupa daftar pertanyaan yang sudah disiapkan terlebih dahulu.

\section{Jenis dan Sumber Data}

Dalam upaya menjawab permasalahan yang ada, maka data yang dibutuhkan sebagai input untuk di analisis adalah berupa data kuantitatif, mengingat dari serangkaian pengukuran, hasilnya dapat dinyatakan dalam bentuk angka, disamping itu jenis data yang relevan untuk dikumpulkan dapat pula diklasifikasikan menurut sumber data. Penelitian ini menggunakan sumber data sekunder yaitu data penelitian yang diperoleh secara tidak langsung yang diperoleh dan dicatat oleh pihak lain yang telah disusun dan dipublikasikan. Data yang diperlukan untuk penelitian ini merupakan data historis, yang diperoleh dari laporan keuangan KSP. Madani NTB.

\section{Identifikasi dan Klasifikasi Variabel \\ Identifikasi Variabel}

Berdasarkan permasalahan yang dikemukakan, variabel-variabel yang di analisis dalam penelitian ini dapat diidentifikasikan, sebagai berikut :

a. Variabel Cost of Loanable Fund (COLF) 
b. Variabel Overhead Cost (OHC)

c. Variabel Risk Cost (Risk)

d. Variabel Tingkat Pajak (Tax Rate)

e. Variabel Return on Equity (ROE)

\section{Klasifikasi Variabel}

Variabel-variabel yang telah diidentifikasikan dapat diklasifikasikan sebagai berikut :

a. Variabel Independen

Variabel ini menjadi sebab berubahnya variabel dependen (variabel terikat). Jadi variabel independen adalah variabel yang mempengaruhi variabel terikat. Variabel independen dalam penelitian ini, adalah variabel : Cost of Loanable Fund (COLF), Overhead Cost (OHC), Risk Cost (Risk), dan Tingkat Pajak (Tax Rate).

b. Variabel Dependen

Variabel dependen sering disebut sebagai variabel terikat. Variabel terikat merupakan variabel yang dipengaruhi oleh variabel independen. Variabel dependen dalam penelitian ini adalah Return on Equiti (ROE).

\section{Definisi Operasional Variabel}

Dalam definisi opersional variabel yang digunakan dalam penelitian ini menunjukkan cara pengukuran dari masing-masing variabel tersebut. Pada setiap indikator dihasilkan dari suatu perhitungan terhadap formulasi yang mendasarkan pada konsep teori dan peraturan-peraturan yang berlaku dalam pengukuran keuangan, terutama pengukuran faktor-faktor Base Lending Rate terhadap Return on Equity pada KSP. Madani NTB, Variabel bebas (independent variable)

1. Variabel bebas (independent variable)

Adapun variabel-variabel independen tersebut adalah sebagai berikut :

a. Cost of Loanable Fund/COLF(X $\mathbf{1})$

Merupakan biaya dana yang dioperasionalkan oleh koperasi untuk memperoleh pendapatan, setelah memperhitungkan cadangan likuiditas dalam bentuk kas dan bank.

b. Overhead Cost/OHC ( $\left.\mathrm{X}_{2}\right)$

Merupakan seluruh biaya yang dikeluarkan oleh koperasi selain bunga dalam proses penghimpunan dana dari berbagai sumber dana.

c. Risk Cost $\left(\mathrm{X}_{3}\right)$

Merupakan potensi risiko kredit atas kredit yang bermasalah dengan membandingkan dengan jumlah saldo kredit yang berhasil disalurkan oleh koperasi.

d. Tax Rate $\left(\mathrm{X}_{\mathbf{4}}\right)$

Merupakan jumlah kewajiban pajak perusahaan yang harus disetorkan kepada pemerintah atas penempatan dana pada kredit, 
yaitu membandingkan antara jumlah pajak yang disetor dengan saldo pinjaman diberikan.

2. Variabel terikat (dependent variable)

Yang menjadi variabel dependen dalam penelitian ini adalah Return on Equity, merupakan perbandingan antara SHU yang dibagikan kepada anggota dengan jumlah modal sendiri yang dimiliki.

\section{Prosedur Analisis Data}

Untuk menganalisis hubungan faktor-faktor Base Lending Rate dengan Return on Equity, maka akan dilakukan perhitungan data, dengan langkahlangkah sebagai berikut:

a. Menghitung Rasio Cost of Loanable Fund/COLF, dengan langkahlangkah :

1) Menghitung nilai jumlah dana yang bisa digunakan untuk dialokasikan dalam bentuk aktiva produktif (loanable fund), yang didapat dari pengurangan total jumlah dana yang berhasil dihimpun dengan jumlah dana yang digunakan untuk cadangan likuiditas (unloanable fund)

2) Menghitung jumlah biaya bunga yang dikeluarkan oleh koperasi.

3) Menghitung Rasio Cost of Loanable Fund/COLF, dengan formula : Total Biaya Dana

$$
\text { COLF = } \quad \text { Total Dana - Unloanable Fund }
$$

b. Menghitung Rasio Overhead Cost, dengan langkah-langkah :

1) Menghitung seluruh biaya dalam proses penghimpunan dana dikurangi bunga.

2) Hasil penjumlahan tersebut dibagi dengan dana yang berhasil dihimpun, dengan formula :

Total Biaya Dana selain Bunga

$$
\mathrm{OHC}=\quad \text {----------------- } \times 100 \%
$$

\section{Total Dana}

c. Menghitung Rasio Risk Cost, dengan langkah-langkah :

1) Menghitung besarnya perkiraan risiko pinjaman bermasalah, sebagai berikut :

a. $50 \%$ dari pinjaman diberikan yang kurang lancar $(\mathrm{KL})$

b. $75 \%$ dari pinjaman diberikan yang diragukan (D)

c. $100 \%$ dari pinjaman diberikan yang macet (M).

2) Hasil penjumlahan tersebut dibagi dengan pinjaman yang disalurkan dengan formula ditetapkan berdasarkan Peraturan Deputi Bidang Pengawasan Kementerian Koperasi dan UKM Republik Indonesia No. 06/PER/DEP.6/IV/2016, sebagai sebagai berikut :

$$
(50 \% \times \mathrm{KL})+(75 \% \times \mathrm{D})+(100 \% \times \mathrm{M})
$$

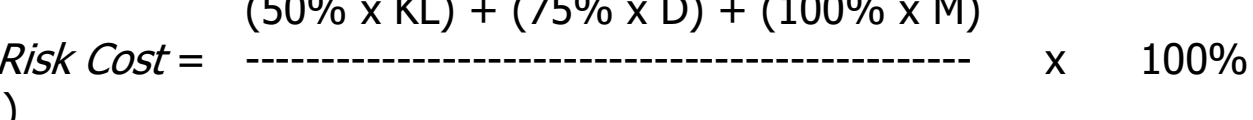


Pinjaman Diberikan

d. Menghitung Rasio Tax Rate, dengan langkah-langkah :

1) Menghitung jumlah kewajiban pajak yang harus disetor.

2) Hasil penjumlahan tersebut dibagi dengan pinjaman yang disalurkan dengan formula :

Total Pembayaran Pajak

Risk Cost $=$ Pinjaman Diberikan

e. Menghitung Rasio Return on Equity, dengan langkah-langkah :

1) Menghitung sisa hasil usaha (SHU) bagian anggota, pembagian SHU anggota adalah $40 \%$ dari jumlah SHU tahun berjalan setalah dikurangi pajak pasal 25 badan.

2) Menghitung nilai modal sendiri koperasi, yang merupakan jumlah dari simpanan pokok, simpanan wajib dan simpanan lain yang memiliki karakteristik sama dengan simpanan pokok dan wajib.

3) Menghitung Rasio Return on Equity, dengan formula :

SHU bagian anggota

ROE $=-\cdots$

Modal Sendiri

\section{Teknik Analisis dan Uji Hipotesis}

Teknik analisis

Teknik analisis yang digunakan adalah analisis terhadap data kuantitatif, dimana beberapa faktor yang mempengaruhi Return on Equity, baik secara parsial maupun secara simultan diperhitungkan secara kuantitatif. Hubungan fungsional antara satu variabel dependen dengan variabel independen dapat dilakukan dengan model regresi. Adapun tujuan analisis ini adalah untuk memperoleh gambaran mengenai pengaruh faktorfaktor Base Lending Rate terhadap Return on Equity pada KSP. Madani NTB, baik secara parsial maupun secara simultan dengan menggunkan bantuan program komputer Statistical Package for social(SPSS) 17.0 for window.

Model regresi berganda dalam penelitian ini dapat diformulasikan sebagai berikut : Pengaruh Cost of Loanable Fund/COLF, Overhead Cost/OHC, Risk Cost, Tax Rate terhadap Return on Equity pada KSP. Madani NTB, yaitu :

$Y=a+\beta_{1} X_{1}+\beta_{2} X_{2}+\beta_{3} X_{3}+\beta_{4} X_{4} \quad+U_{1}$

Keterangan:

Y $\quad=$ Return on Equity

a $\quad=$ Konstanta

$\beta_{1} \ldots \beta_{4}=$ Koefisien regresi

$\mathrm{X}_{1}=$ Cost of Loanable Fund/COLF

$\mathrm{X}_{2}=$ Overhead Cost/OHC 


$$
\begin{array}{ll}
\mathrm{X}_{\mathbf{3}} & =\text { Risk Cost } \\
\mathrm{X}_{\mathbf{4}} & =\text { Tax Rate } \\
\mathrm{U}_{1} & =\text { Variabel pengganggu }
\end{array}
$$

\section{Uji Parsial (t-test) dan Simultan (F-test)}

1. Pengujian terhadap koefisien regresi secara parsial (t-test)

Pengujian ini dilakukan dengan uji t dimana pengujian ini bertujuan untuk mengetahui signifikansi peran secara parsial antara variabel independen terhadap variabel dependen, dan variabel independen lainnya diasumsikan dianggap konstan. "Uji statistik t pada dasarnya menunjukkan seberapa jauh pengaruh satu variabel penjelas secara individual dalam menerangkan variasi variabel terikat" (Kuncoro,2007:81). Dalam pengujian ini akan dilihat arah signifikansi pengaruh tiap-tiap variabel faktor-faktor Base Lending Rata, dengan cara sebagai berikut :

Dengan tingkat signifikansi sebesar $5 \%$, nilai $t$ hitung dari masingmasing koefisien regresi, kemudian dibandingkan dengan $t$ tabel :

1) Jika $t$ hitung $>t$ tabel, maka masing-masing variabel cost of Loanable Fund, Overhead Cost, Risk Cost, Tax Rate berpengaruh signifikan terhadap Return on Equty.

2) Jika $\mathrm{t}$ hitung $<\mathrm{t}$ tabel, hal ini menunjukkan masing-masing variabel Cost of Loanable Fund, Overhead Cost, Risk Cost, Tax Rate tidak berpengaruh signifikan terhadap Return on Equty.

2. Pengujian terhadap koefisien regresi secara simultan (F-test)

Pengujian ini digunakan untuk menyatakan bahwa ada pengaruh secara simultan dari variabel Cost of Loanable Fund, Overhead Cost, Risk Cost, Tax Rate terhadap Return on Equty pada KSP. Madani NTB dan variabel yang paling dominan berpengaruh signifikan terhadap Return on Equty.

Pelaksanaan pengujian ini dilaksanakan dengan menggunakan uji $F$. "Uji statistik F pada dasarnya menunjukkan apakah semua variabel bebas yang dimasukkan dalam model mempunyai pengaruh secara bersama-sama terhadap variabel terikat" (Kuncoro,2007:82). Dengan tingkat signifikansi sebesar 5\%, kemudian dilakukan perbandingan antara nilai Fratio dari masing-masing koefisien regresi dengan nilai $F_{\text {tabel }}$ :

a. Jika $\mathrm{F}_{\text {ratio }}>\mathrm{F}_{\text {tabel, }}$, hal ini menunjukkan bahwa secara simultan variabel Cost of Loanable Fund, Overhead Cost, Risk Cost, Tax Rate berpengaruh positif terhadap Return on Equty.

b. Jika $\mathrm{F}_{\text {ratio }}<\mathrm{F}$ tabel, hal ini menunjukkan bahwa secara simultan variabel Cost of Loanable Fund, Overhead Cost, Risk Cost, Tax Rate tidak berpengaruh positif terhadap Return on Equty.

\section{Uji Asumsi Klasik}

Sebelum model regresi linier berganda digunakan untuk menguji hipotesis, terlebih dahulu dilakukan pengujian asumsi klasik agar model 
regresi yang diperoleh dari metode kuadrat terkecil nantinya menghasilkan penaksir yang tidak bias linear terbaik (Best Linear Unbias Estimatior), sehingga hasil perhitungan dapat diinterpretasikan dengan efisien dan akurat.

"Dalam melaksanakan pengujian ini, beberapa asumsi klasik yang dipergunakan untuk model regresi berganda" (Gujarati,1999:153) adalah :

a. Data terdistribusi secara normal.

b. Tidak terdapat auto korelasi antara variabel independen.

c. Tingkat gangguan dari variabel independen seragam atau homoskedastik atau dengan kata lain tidak terdapat heteroskedastisitas.

d. Tidak terdapat multikolonearitas antara variabel independen.

Dengan memperhatikan asumsi tersebut diatas, maka langkahlangkah pengujian selanjutnya adalah :

1) Uji Asumsi Klasik Normalitas.

Uji asumsi ini akan menguji data variabel bebas $(X)$ dan data variabel terikat $(\mathrm{Y})$ pada persaamaan regresi yang dihasilkan, apakah berdistribusi normal atau berdistribusi tidak normal. "Persamaan regresi dikatakan baik, jika mempunyai data variabel bebas dan data variabel terikat berdistribusi mendekati normal atau normal sama sekali".(Sunyoto,2009:84). "Dalam pembahasan ini akan digunakan uji Normal Probability Plot dengan membandingkan data riil dengan data distribusi normal secara komulatif, dan suatu data dikatakan berdistribusi normal jika garis data riil mengikuti garis diagonal"(Sunyoto,2009:89).

2) Uji Asumsi Klasik Multikolinearitas

"Uji ini bertujuan untuk mengukur tingkat asosiasi (keeratan) hubungan/pengaruh antar variabel bebas tersebut melalui besaran koefisien korelasi ( $r$ ). Dalam menentukan ada tidaknya multikolinearitas, dapat digunakan cara lain", (Sunyoto,2009:79) yaitu dengan menentukan nilai tolerance dengan menggunakan alpha/tolerance $=10 \%$ atau 0,10 maka variance inflation factor $(\mathrm{VIF})=10$. Variabel bebas tidak mengalami multikolinieritas jika $\mathrm{VIF}_{\text {hitung }}<\mathrm{VIF}$, dan tolerance variabel bebas di atas $10 \%$

3) Uji Asumsi Klasik Heteroskedastisitas.

Persamaan regresi yang baik adalah, jika tidak terjadi heteroskedastisitas, dapat terjadi jika variansnya tidak sama atau berbeda. "Analisis uji asumsi heteroskedastisitas hasil output SPSS melalui grapik scatterplot antara $\mathrm{Z}$ prediction (ZPRED) yang merupakan variabel bebas (sumbu $\mathrm{X}=\mathrm{Y}$ hasil prediksi) dan nilai residualnya (SRESID) merupakan variabel terikat (sumbu $Y=Y$ prediksi $-Y$ riil)" (Sunyoto,2009:82), dimana

a. Homoskedastisitas terjadi jika pada scatterplot titik-titik hasil pengolahan data antara ZPRED dan SRESID menyebar di bawah ataupun di atas titik origin (angka 0) pada sumbu $Y$ dan tidak mempunyai pola yang teratur. 
b. Heteroskedastisitas terjadi, jika pada scatterplot titik-titiknya mempunyai pola yang teratur, baik menyempit, melebar maupun bergelombang-gelombang.

4) Uji Asumsi Klasik Autokorelasi.

Terjadinya autokorelasi, jika ada korelasi secara linier antara kesalahan penggangu periode $t$ (berada) dan keslahan penggangu periode $\mathrm{t}-1$ (sebelumnya).

" Salah satu ukuran dalam menentukan ada tidaknya masalah autokorelasi dengan uji Durbin-Watson (DW)" (Sunyoto,2009:91), dengan ketentuan sebagai berikut :

a. Terjadi autokorelasi positif, jika nilai DW di bawah -2 (DW < -2).

b. Tidak terjadi autokorelasi, jika nilai DW berada di antara -2 dan +2 atau $-2<\mathrm{DW}<+2$.

c. Terjadi autokorelasi negatif, jika nilai DW di atas +2 atau DW $>$ +2 .

\section{HASIL DAN PEMBAHASAN}

\section{Hasil Penelitian}

\section{Gambaran Umum Obyek Penelitian}

KSP.Madani NTB adalah koperasi primer yang melakukan kegiatan usaha sebagai koperasi simpan pinjam. Koperasi ini didirikan oleh 24 orang anggota pada tanggal 14 Februari 2004, Akta pendirian KSP. Madani NTB ini disahkan badan hukumnya oleh Kepala Dinas Koperasi Dan UKM Provinsi Nusa Tenggara Barat atas nama Menteri Negara Koperasi Dan Usaha Kecil Menengah Republik Indonesia pada tanggal 24 Juni 2004, BH.No.518/217/BH/Diskop dan UKM/VI/2004, dan Akta Perubahan Anggaran Dasar yang disahkan oleh Gubernur NTB atas nama Menteri Negara Koperasi Dan Usaha Kecil Menengah Republik Indonesia pada tanggal 10 Nopember 2005, dengan Badan Hukum No. 518/39/BH/PAD/Dinas Koperasi Dan UKM/XI/2005. Koperasi ini sudah 14 tahun berkiprah dalam perkoperasian, kedudukan kantor pusat di Tanjung, Desa Medana, Kecamatan Tanjung, Kabupaten Lombok Utara, memiliki 3 (tiga) kantor cabang, yaitu : cabang Mataram, cabang Gerung, dan cabang Gangga, serta 1 kantor cabang pembantu di Pagutan, dengan jumlah anggota sebanyak : 6.377 orang. Berikut ini dapat disampaikan kondisi keuangan KSP. Madani NTB periode 2008 - 2017, dapat dilihat pada Tabel 4.1 di bawah ini. 
Tabel 1

Kondisi Keuangan KSP. Madani NTB

Periode : 2008-2017

\begin{tabular}{|c|c|r|r|r|r|r|}
\hline \multirow{2}{*}{ No } & \multirow{2}{*}{ Tahun } & \multicolumn{6}{|c|}{ Kondisi Keuangan (ribuan rupaih ) } \\
\cline { 3 - 8 } & & \multicolumn{1}{|c|}{ Asset } & Kas/Bank & $\begin{array}{c}\text { Total } \\
\text { Kewajiban }\end{array}$ & \multicolumn{1}{c|}{$\begin{array}{c}\text { Modal } \\
\text { Sendiri }\end{array}$} & \multicolumn{1}{c|}{$\begin{array}{c}\text { SHU } \\
\text { Netto }\end{array}$} \\
\hline 1 & 2008 & 6.488 .931 & 880.087 & 4.452 .414 & 473.339 & 148.779 \\
\hline 2 & 2009 & 8.907 .836 & 1.598 .107 & 7.340 .530 & 650.967 & 210.537 \\
\hline 3 & 2010 & 11.410 .510 & 1.016 .197 & 9.322 .392 & 904.139 & 359.069 \\
\hline 4 & 2011 & 13.432 .123 & 2.871 .220 & 11.157 .875 & 1.004 .639 & 271.367 \\
\hline 5 & 2012 & 16.647 .125 & 2.771 .777 & 13.522 .618 & 1.358 .074 & 403.359 \\
\hline 6 & 2013 & 19.187 .216 & 3.752 .244 & 16.022 .632 & 1.604 .133 & 472.803 \\
\hline 7 & 2014 & 19.590 .694 & 4.215 .659 & 17.390 .543 & 2.003 .502 & 799.330 \\
\hline 8 & 2015 & 23.640 .290 & 3.813 .206 & 19.585 .183 & 2.638 .603 & 633.597 \\
\hline 9 & 2016 & 25.193 .391 & 4.811 .496 & 20.963 .264 & 2.956 .053 & 621.666 \\
\hline 10 & 2017 & 27.827 .291 & 5.227 .364 & 22.722 .503 & 3.227 .438 & 671.690 \\
\hline \multicolumn{2}{|c|}{ Jumlah } & 172.325 .411 & 30.957 .361 & 142.469 .958 & 16.820 .892 & 4.590 .198 \\
\hline \multicolumn{2}{|c|}{ Rata-rata } & 17.232 .541 & 3.095 .736 & 14.246 .995 & 1.682 .089 & 459.019 \\
\hline
\end{tabular}

Sumber : Laporan Keuangan KSP.Madani (diolah)

\section{Deskripsi Data}

\section{Penilaian Cost of Loanable Fund}

Untuk Cost of Loanable Fund dengan menggunakan formula rumus 1, dapat dilihat pada Tabel 4.2 di bawah ini, tampak rasio Cost of Loanable Fund koperasi tahun 2008-2017 rata-rata sebesar 16,80 \%, rasio Cost of Loanable Fund tertinggi adalah pada tahun 2011 yaitu sebesar 19,77\%, sedangkan yang terendah pada tahun 2017 yaitu sebesar 15,25\%

Tabel 2

Cost of Loanable Fund KSP.Madani NTB

Periode : $2008-2017$

\begin{tabular}{|c|c|r|r|c|}
\hline No & Tahun & Loanable Fund & Beban Bunga & $\begin{array}{c}\text { Cost of } \\
\text { Loanable } \\
\text { Fund } \\
(\%)\end{array}$ \\
\hline 1 & 2008 & $3.572 .326 .564,00$ & $666.712 .013,00$ & 18,66 \\
\hline 2 & 2009 & $5.742 .423 .955,00$ & $1.087 .556 .015,00$ & 18,94 \\
\hline 3 & 2010 & $8.306 .195 .374,00$ & $1.392 .300 .042,00$ & 16,76 \\
\hline 4 & 2011 & $8.276 .654 .311,00$ & $1.636 .647 .651,00$ & 19,77 \\
\hline 5 & 2012 & $10.750 .840 .652,00$ & $1.871 .778 .268,00$ & 17,41 \\
\hline 6 & 2013 & $12.270 .388 .589,00$ & $2.062 .549 .015,00$ & 16,81 \\
\hline 7 & 2014 & $13.174 .883 .812,00$ & $2.134 .509 .539,00$ & 16,20 \\
\hline 8 & 2015 & $15.771 .977 .310,00$ & $2.601 .841 .558,00$ & 16,50 \\
\hline 9 & 2016 & $16.151 .767 .994,00$ & $2.616 .339 .538,00$ & 16,20 \\
\hline
\end{tabular}




\begin{tabular}{|c|c|r|r|c|}
\hline 10 & 2017 & $17.495 .138 .681,00$ & $2.668 .314 .664,00$ & 15,25 \\
\hline Jumlah & $111.512 .597 .242,00$ & $18.738 .548 .303,00$ & \multirow{2}{*}{16,80} \\
\hline Rata-rata & $11.151 .259 .724,00$ & $1.873 .854 .830,00$ & \\
\hline
\end{tabular}

Sumber : Laporan Keuangan KSP.Madani NTB (diolah)

\section{Penilaian Overhead Cost}

Untuk menghitung rasio Overhead Cost dengan menggunakan formula rumus 2, dapat dilihat pada Tabel 3 di bawah ini, sebagai berikut :

Tabel 4.3

Overhead Cost KSP.Madani NTB

Periode : 2008 - 2017

\begin{tabular}{|c|c|r|r|c|}
\hline No & Tahun & \multicolumn{1}{c|}{ Total Dana } & \multicolumn{1}{c|}{$\begin{array}{c}\text { Beban Diluar } \\
\text { Bunga }\end{array}$} & \multicolumn{1}{c|}{$\begin{array}{c}\text { Overhead } \\
\text { Cost }(\%)\end{array}$} \\
\hline 1 & 2008 & $4.452 .414 .446,00$ & $569.639 .878,00$ & 12,79 \\
\hline 2 & 2009 & $7.340 .530 .863,00$ & $843.486 .063,00$ & 11,49 \\
\hline 3 & 2010 & $9.322 .392 .651,00$ & $1.107 .583 .009,00$ & 11,88 \\
\hline 4 & 2011 & $11.157 .875 .188,00$ & $1.320 .292 .025,00$ & 11,84 \\
\hline 5 & 2012 & $13.522 .618 .326,00$ & $1.323 .226 .745,00$ & 9,79 \\
\hline 6 & 2013 & $16.022 .632 .817,00$ & $1.500 .352 .547,00$ & 9,36 \\
\hline 7 & 2014 & $17.390 .543 .246,00$ & $1.709 .307 .407,00$ & 9,83 \\
\hline 8 & 2015 & $19.585 .183 .598,00$ & $1.878 .191 .602,00$ & 9,59 \\
\hline 9 & 2016 & $20.963 .264 .650,00$ & $2.003 .972 .437,00$ & 9,56 \\
\hline 10 & 2017 & $22.722 .503 .020,00$ & $2.110 .021 .449,00$ & 9,29 \\
\hline \multicolumn{2}{|c|}{ Jumlah } & $142.469 .958 .805,00$ & $14.366 .073 .162,00$ & 10,08 \\
\hline \multicolumn{2}{|c|}{ Rata-rata } & $14.246 .995 .880,00$ & $1.436 .607 .316,00$ & 10 \\
\hline
\end{tabular}

Sumber : Laporan Keuangan KSP.Madani NTB (diolah)

Berdasarkan Tabel 4.3 di atas tampak rasio Overhead Cost koperasi tahun 2008-2017 rata-rata sebesar 10,08 \%, rasio Overhead Cost tertinggi adalah pada tahun 2008 yaitu sebesar 12,79\%, sedangkan yang terendah pada tahun 2017 yaitu sebesar $9,29 \%$

\section{Penilaian Risk Cost}

Untuk menghitung rasio Risk Cost dengan menggunakan formula rumus 3, dapat dilihat pada Tabel 4.4 di bawah. Dimana tampak rasio Risk Cost koperasi tahun 2008-2017 rata-rata sebesar 4,29\%, rasio Risk Cost tertinggi adalah pada tahun 2016 yaitu sebesar 7,23\%, sedangkan yang terendah pada tahun 2009 yaitu sebesar 1,68\% sebagaimana dapat dijelaskan dalam Tabel 4.4 di bawah ini, sebagai berikut : 
Tabel 4.4. Risk Cost KSP.Madani NTB Periode : $2008-2017$

\begin{tabular}{|c|c|c|c|c|}
\hline No & Tahun & Pinjaman Diberikan & $\begin{array}{c}\text { Potensi Risiko } \\
\text { Kredit }\end{array}$ & $\begin{array}{c}\text { Risk Cost } \\
\text { (\%) }\end{array}$ \\
\hline 1 & 2008 & $4.255 .705 .981,00$ & $72.136 .428,00$ & 1,70 \\
\hline 2 & 2009 & $7.018 .848 .724,00$ & $118.154 .459,00$ & 1,68 \\
\hline 3 & 2010 & $7.864 .185 .256,00$ & $221.538 .114,00$ & 2,82 \\
\hline 4 & 2011 & $8.813 .984 .923,00$ & $213.267 .250,00$ & 2,42 \\
\hline 5 & 2012 & $9.413 .940 .688,00$ & $218.452 .899,00$ & 2,32 \\
\hline 6 & 2013 & $11.543 .025 .719,00$ & $215.174 .924,00$ & 2,21 \\
\hline 7 & 2014 & $11.535 .695 .173,00$ & $369.887 .206,00$ & 3,21 \\
\hline 8 & 2015 & $13.375 .305 .377,00$ & $941.477 .585,00$ & 7,04 \\
\hline 9 & 2016 & $14.267 .613 .855,00$ & $1.032 .082 .983,00$ & 7,23 \\
\hline 10 & 2017 & 13.792.192.797,00 & $924.606 .281,00$ & 6,70 \\
\hline \multicolumn{2}{|c|}{ Jumlah } & $101.880 .498 .493,00$ & $4.366 .778 .128,00$ & \multirow{2}{*}{4,29} \\
\hline \multicolumn{2}{|c|}{ Rata-rata } & $10,188.049 .849,00$ & $436.677 .812,00$ & \\
\hline
\end{tabular}

Sumber : Laporan Keuangan KSP.Madani NTB (diolah)

\section{Penilaian Tax Rate}

Untuk menghitung Tax Rate dengan menggunakan formula rumus 4, dapat dilihat pada Tabel 4.5 di bawah ini, tampak Tax Rate koperasi tahun 2008-2017 rata-rata sebesar 0,40\%, Tax Ratio tertinggi adalah pada tahun 2008 yaitu sebesar 0,91\%, sedangkan yang terendah pada tahun 2011 yaitu sebesar $0,23 \%$

Tabel 4.5 Tax Rate KSP.Madani NTB Periode : 2008 - 2017

\begin{tabular}{|c|c|r|r|c|}
\hline No & Tahun & Pinjaman Diberikan & $\begin{array}{c}\text { Kewajiban } \\
\text { Pajak }\end{array}$ & $\begin{array}{c}\text { Tax Rate } \\
(\%)\end{array}$ \\
\hline 1 & 2008 & $4.255 .705 .981,00$ & $38.762 .665,00$ & 0,91 \\
\hline 2 & 2009 & $7.018 .848 .724,00$ & $24.808 .000,00$ & 0,35 \\
\hline 3 & 2010 & $7.864 .185 .256,00$ & $36.961 .670,00$ & 0,47 \\
\hline 4 & 2011 & $8.813 .984 .923,00$ & $20.112 .000,00$ & 0,23 \\
\hline 5 & 2012 & $9.413 .940 .688,00$ & $41.254 .000,00$ & 0,44 \\
\hline 6 & 2013 & $11.543 .025 .719,00$ & $22.555 .000,00$ & 0,20 \\
\hline 7 & 2014 & $11.535 .695 .173,00$ & $44.626 .000,00$ & 0,39 \\
\hline 8 & 2015 & $13.375 .305 .377,00$ & $47.432 .000,00$ & 0,35 \\
\hline 9 & 2016 & $14.267 .613 .855,00$ & $48.374 .000,00$ & 0,34 \\
\hline 10 & 2017 & $13.792 .192 .797,00$ & $79.382 .000,00$ & 0,58 \\
\hline \multicolumn{2}{|c|}{ Jumlah } & $101.880 .498 .493,00$ & $404.267 .335,00$ & 0,40 \\
\hline \multicolumn{2}{|c|}{ Rata-rata } & $10,188.049 .849,00$ & $40.426 .733,00$ & \multirow{2}{*}{. } \\
\hline
\end{tabular}

Sumber : Laporan Keuangan KSP.Madani NTB (diolah)

\section{Penilaian Return on Equity}

Untuk menghitung rasio Return on Equity menggunakan formula rumus 5, dapat dilihat pada Tabel 4.6 di bawah ini, tampak rasio Return on 
Equity koperasi tahun 2008-2017 rata-rata sebesar 10,61\%, rasio Return on Equity tertinggi pada tahun 2010 sebesar 15,80\%, terendah tahun 2017 sebesar $8,32 \%$

Tabel 4.6 Return on Equity KSP.Madani NTB Periode : 2008 - 2017

\begin{tabular}{|c|c|r|r|c|}
\hline No & Tahun & Modal Sendiri & \multicolumn{1}{c|}{$\begin{array}{c}\text { SHU Bagian } \\
\text { Anggota }\end{array}$} & $\begin{array}{c}\text { Return on } \\
\text { Equity } \\
(\%)\end{array}$ \\
\hline 1 & 2008 & $473.339 .003,00$ & $66.950 .803,00$ & 14,14 \\
\hline 2 & 2009 & $650.967 .132,00$ & $89.478 .497,00$ & 13,75 \\
\hline 3 & 2010 & $904.139 .523,00$ & $142.827 .640,00$ & 15,80 \\
\hline 4 & 2011 & $1.004 .639 .963,00$ & $100.501 .878,00$ & 10,00 \\
\hline 5 & 2012 & $1.358 .074 .826,00$ & $144.842 .258,00$ & 10,67 \\
\hline 6 & 2013 & $1.604 .133 .782,00$ & $189.121 .123,00$ & 11,79 \\
\hline 7 & 2014 & $2.003 .502 .357,00$ & $280.130 .000,00$ & 13,98 \\
\hline 8 & 2015 & $2.638 .603 .029,00$ & $253.440 .000,00$ & 9,61 \\
\hline 9 & 2016 & $2.956 .053 .830,00$ & $248.666 .000,00$ & 8,41 \\
\hline 10 & 2017 & $3.227 .438 .619,00$ & $268.672 .000,00$ & 8,32 \\
\hline \multicolumn{2}{|c|}{ Jumlah } & $16.820 .892 .064,00$ & $1.784 .630 .199,00$ & \multirow{2}{*}{10,61} \\
\hline \multicolumn{2}{|c|}{ Rata-rata } & $1.682 .089 .206,00$ & $178.463 .019,00$ & \\
\hline
\end{tabular}

Sumber : Laporan Keuangan KSP.Madani NTB (diolah)

Berdasarkan Tabel 4.6 di atas tampak rasio Return on Equity koperasi tahun 2008-2017 rata-rata sebesar 10,61\%, rasio Return on Equity tertinggi adalah pada tahun 2010 yaitu sebesar $15,80 \%$, sedangkan yang terendah pada tahun 2017 yaitu sebesar $8,32 \%$

\section{Analisis Hasil}

Pengujian menggunakan analisis regresi berganda, bertujuan untuk menguji hipotesis yang diajukan dalam penelitian ini, yaitu untuk menguji secara parsial signifikan maupun secara simultan siginifikan dari variabelvariabel independen yang terdiri dari $\operatorname{COLF}\left(\mathrm{X}_{1}\right), \operatorname{OHC}\left(\mathrm{X}_{2}\right), \operatorname{RISK}\left(\mathrm{X}_{3}\right)$, dan TAX $\left(\mathrm{X}_{4}\right)$, terhadap variabel dependen yaitu Return on Equity Pada KSP. Madani NTB. Pengujian hipotesis dilakukan dengan Uji t untuk menguji pengaruh masing-masing variabel independen terhadap variabel dependen, sedangkan Uji $F$ untuk menguji pengaruh variabel independen secara simultan terhadap variabel dependen.

\section{Uji Asumsi Klasik}

Untuk menganalisis dengan menggunakan model regresi linier berganda, sebelum model regresi linier berganda digunakan untuk menguji hipotesis, terlebih dahulu dilakukan pengujian asumsi klasik agar model regresi yang diperoleh dari metode kuadrat terkecil nantinya menghasilkan penaksir yang tidak bias linear terbaik (Best Linear Unbias Estimatior), 
sehingga hasil perhitungan dapat diinterpretasikan dengan efisien dan akurat. Dengan memperhatikan asumsi tersebut diatas, maka langkahlangkah pengujian selanjutnya sebagai berikut :

\section{Uji Asumsi Klasik Multikolinearitas}

Uji ini bertujuan untuk mengukur tingkat asosiasi (keeratan) hubungan/pengaruh antar variabel bebas tersebut melalui besaran koefisien korelasi. Pengujian dilakukan dengan menggunakan program SPSS, sehingga diperoleh hasil pada Tabel 4.7 sebagai berikut :

Tabel 4.7

Hasil Pengujian Multikolonearitas

\begin{tabular}{|c|c|c|c|}
\hline \multicolumn{4}{|c|}{ Coefficients $^{a}$} \\
\hline \multirow{2}{*}{\multicolumn{2}{|c|}{ Model }} & \multicolumn{2}{|c|}{ Collinearity Statistics } \\
\hline & & Tolerance & VIF \\
\hline \multirow[t]{4}{*}{1} & COLF & .247 & 4.049 \\
\hline & $\mathrm{OHC}$ & .220 & 4.548 \\
\hline & RISK & .510 & 1.962 \\
\hline & TAX & .534 & 1.871 \\
\hline
\end{tabular}

a. Dependent Variable: ROE

Sumber : Hasil output program SPSS

Berdasarkan hasil pengujian multikolonearitas seperti pada Tabel 4.7, di atas dapat dilihat bahwa nilai VIF (Variance Inflation Factor) dari setiap variabel independen $\operatorname{COLF}\left(\mathrm{X}_{1}\right)=4.049, \operatorname{OHC}\left(\mathrm{X}_{2}\right)=4.548$, Risk $\left(\mathrm{X}_{3}\right)=1.962$, dan $\operatorname{Tax}\left(\mathrm{X}_{4}\right)=1.871$ ternyata lebih kecil 10 dan semua tolerance variabel bebas di atas 10\%, maka dapat disimpulkan bahwa antar variabel bebas tidak terjadi multikolinearitas.

\section{Uji Asumsi Klasik Heteroskedastisitas}

Persamaan regresi yang baik adalah, jika tidak terjadi heteroskedastisitas, dapat terjadi jika variansnya tidak sama atau berbeda. "Analisis uji asumsi heteroskedastisitas hasil output SPSS melalui grapik scatterplot antara Z prediction (ZPRED) yang merupakan variabel bebas (sumbu $X=Y$ hasil prediksi) dan nilai residualnya (ZRESID) merupakan variabel terikat (sumbu $Y=Y$ prediksi $-Y$ riil). Pengujian dilakukan dengan menggunakan program SPSS, sehingga diperoleh hasil pada Gambar 4.1 di bawah ini, didapatkan titik-titik menyebar di bawah serta di atas sumbu $Y$, dan tidak mempunyai pola yang teratur. Jadi dapat disimpulkan bahwa variabel bebas $\operatorname{COLF}\left(\mathrm{X}_{1}\right)$, OHC $\left(\mathrm{X}_{2}\right)$, Risk $\left(\mathrm{X}_{3}\right)$, dan Tax $\left(\mathrm{X}_{4}\right)$, tidak terjadi heterokedastisitas, sehingga model regresi ini layak digunakan untuk memperkirakan variabel dependen (ROE). 
Gambar 4.1

Grafik Uji Heterokedatisitas

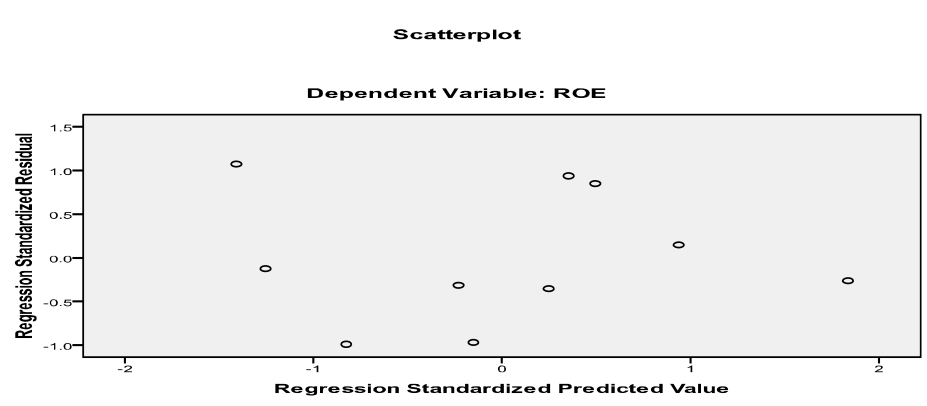

Sumber : Hasil output program SPSS

\section{Uji Asumsi Klasik Autokorelasi}

Tujuan dari uji ini adalah untuk mengetahui apakah dalam sebuah model regresi linier ada korelasi secara linier antara kesalahan pengganggu periode $\mathrm{t}$ (berada) dan kesalahan pengganggu periode $\mathrm{t}-1$ (sebelumnya), jika terdapat korelasi, maka terjadi problem autokorelasi. Pengujian dengan menggunakan uji Durbin Watson (D-W) dilakukan dengan menggunakan SPSS, sebagaimana dapat dijelaskan pada Tabel 4.8 "Salah satu ukuran dalam menentukan ada tidaknya masalah autokorelasi dengan uji DurbinWatson (DW)" (Sunyoto,2009:91), dengan ketentuan sebagai berikut :

a. Terjadi autokorelasi positif, jika nilai DW di bawah -2 (DW $<-2)$.

b. Tidak terjadi autokorelasi, jika nilai DW berada di antara -2 dan +2 atau $-2<\mathrm{DW}<+2$.

c. Terjadi autokorelasi negatif, jika nilai DW di atas +2 atau DW $>+2$.

Tabel 4.8

Hasil Pengujian Autokorelasi

\section{Model Summaryb}

\begin{tabular}{|c|r|}
\hline Model & Durbin-Watson \\
\hline 1 & 1.335 \\
\hline
\end{tabular}

a. Predictors: (Constant), TAX, COLF, ISK, OHC

b. Dependent Variable: ROE

Sumber : Hasil output program SPSS

Dari hasil tersebut di atas, diperoleh Durbin-Watson sebesar 1.335, maka nilai Durbin-Watson yang diperoleh berada diantara -2 dan +2 . Hal ini berarti bahwa dalam model tersebut tidak terdapat masalah autokorelasi, sehingga dapat disimpulkan bahwa model yang digunakan ini memenuhi kriteria ekonometrik, yang mana model dapat dinyatakan nonautokorelasi

\section{Uji Asumsi Klasik Normalitas}

Uji asumsi ini akan menguji data variabel bebas $(X)$ dan data variabel terikat $(Y)$ pada persaamaan regresi yang dihasilkan, apakah berdistribusi 
normal atau berdistribusi tidak normal. "Dalam pembahasan ini akan di uji dengan menggunakan Normal Probability Plots, data dinyatakan berdistribusi normal jika garis data riil mengikuti garis diagonal"(Sunyoto,2008:89). Pengujian dengan menggunakan bantuan program SPSS, sehingga diperoleh hasil pada gambar 4.2 di bawah ini.

Gambar 4.2

Hasil Pengujian Normalitas

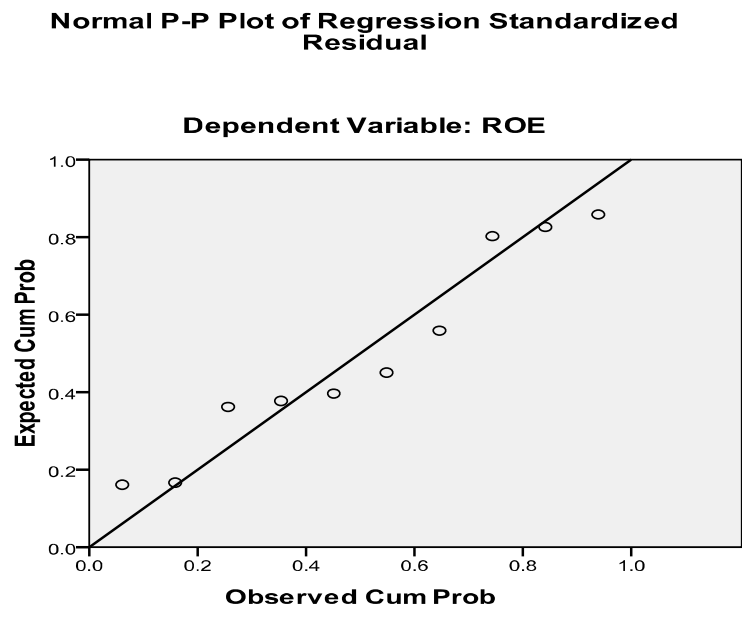

Sumber : Hasil output program SPSS

Dari hasil gambar 4.2 di atas menunjukkan berdistribusi normal karena garis (titik-titik) mengikuti garis diagonal.

\section{Hasil Estimasi Regresi Linier Berganda}

Pengujian menggunakan analisis regresi linier berganda, bertujuan untuk menguji secara parsial signifikan maupun secara simultan siginifikan dari variabel-variabel independen yang terdiri dari variabel $\operatorname{COLF}\left(X_{1}\right), \mathrm{OHC}$ $\left(\mathrm{X}_{2 .}\right)$, $\operatorname{RISK}\left(\mathrm{X}_{3}.\right)$, dan $\operatorname{TAX}\left(\mathrm{X}_{4}\right)$ ) terhadap variabel dependen yaitu Return on Equity pada KSP.Madani NTB. Pengujian dilakukan dengan Uji t untuk menguji pengaruh masing-masing variabel independen terhadap variabel dependen, sedangkan Uji F untuk menguji pengaruh variabel independen secara simultan terhadap variabel dependen.

\section{Uji Parsial (Uji t)}

Pengujian hipotesis dengan Uji t dilakukan dengan bantuan program SPSS, adapun hasilnya seperti pada Tabel 4.9 di bawah ini. 
Tabel 4.9

Hasil Pengujian Hipotesis Dengan Uji t

\section{Coefficients $^{\mathrm{a}}$}

\begin{tabular}{|c|c|c|c|c|c|c|}
\hline \multirow{2}{*}{\multicolumn{2}{|c|}{ Model }} & \multicolumn{2}{|c|}{$\begin{array}{l}\text { Unstandardized } \\
\text { Coefficients }\end{array}$} & \multirow{2}{*}{\begin{tabular}{|c|}
$\begin{array}{c}\text { Standardized } \\
\text { Coefficients }\end{array}$ \\
Beta \\
\end{tabular}} & \multirow[b]{2}{*}{$\mathrm{t}$} & \multirow[b]{2}{*}{ Sig. } \\
\hline & & B & Std. Error & & & \\
\hline \multirow[t]{5}{*}{1} & $\begin{array}{l}\text { (Consta } \\
\text { nt) }\end{array}$ & 28.749 & 8.202 & & 3.505 & .01 \\
\hline & COLF & -1.977 & .618 & -1.071 & -3.199 & .02 \\
\hline & $\mathrm{OHC}$ & 2.086 & .718 & 1.031 & 2.906 & .03 \\
\hline & RISK & -.966 & .268 & -.841 & -3.606 & .015 \\
\hline & TAX & -3.239 & 2.965 & -.249 & -1.092 & .32 \\
\hline
\end{tabular}

a. Dependent Variable: ROE

Sumber : Hasil output program SPSS

Dari hasil pengujian pada Tabel 4.9 tersebut di atas, maka diperoleh koefisien regresi pada persamaan regresi berganda sebagai berikut :

$Y=28.749-1.977 X_{1}+2.086 X_{2}-966 X_{3}-3.239 X_{4}$

dimana

$\mathrm{Y}=\mathrm{ROE}, \mathrm{X}_{1}=\mathrm{COLF}, \mathrm{X}_{2}=\mathrm{OHC}, \mathrm{X}_{3}=$ Risk, $\mathrm{X}_{4}=\operatorname{Tax}$

Nilai konstanta (a) sebesar 28.749 artinya ketika variabel $\operatorname{COLF}\left(X_{1}\right)$, $\mathrm{OHC}\left(\mathrm{X}_{2}\right)$, Risk $\left(\mathrm{X}_{3}\right)$, dan Tax $\left(\mathrm{X}_{4}\right)$, diasumsikan sama dengan nol, maka ROE pada KSP. Madani NTB akan positif sebesar $28,749 \%$.

Nilai koefesien $\beta_{1}\left(\mathrm{COLF} / \mathrm{X}_{1}\right)$ sebesar 1.977 artinya jika variabel independen lainnya nilainya tetap dan $\operatorname{COLF}\left(X_{1}\right)$ mengalami kenaikan $1 \%$, maka ROE (Y) akan mengalami penurunan sebesar 1,977\%. Koefisien bernilai begatif artinya terjadi hubungan negatif antara COLF dengan ROE, semakin meningkat COLF, maka semakin turun ROE.

Nilai koefesien $\beta_{2}\left(\mathrm{OHC} / X_{2}\right)$ sebesar 2.086 artinya jika variabel independen lainnya tetap dan $\mathrm{OHC}$ mengalami kenaikan $1 \%$, maka ROE (Y) akan mengalami peningkatan sebesar 2,086\%. Koefisien bernilai positif artinya terjadi hubungan positif antara $\mathrm{OHC}$ dengan $\mathrm{ROE}$, semakin naik $\mathrm{OHC}$ maka semakin meningkat ROE.

Nilai koefesien $\beta_{3}\left(R i s k / X_{3}\right)$ sebesar 966 artinya jika variabel independen lainnya nilainya tetap dan Risk $\left(\mathrm{X}_{3}\right)$ mengalami kenaikan $1 \%$, maka ROE $(Y)$ akan mengalami penurunan sebesar 0,966\%. Koefisien bernilai negatif artinya terjadi hubungan negatif antara Risk dengan ROE, semakin naik Risk maka semakin turun ROE.

Nilai koefesien $\beta_{4}\left(\operatorname{Tax} / X_{4}\right)$ sebesar 3.239 artinya jika variabel independen lainnya nilainya tetap dan $\operatorname{Tax}\left(\mathrm{X}_{4}\right)$ mengalami kenaikan $1 \%$, maka ROE $(Y)$ akan mengalami penurunan sebesar 3,239\%. Koefisien 
bernilai negatif artinya terjadi hubungan negatif antara Tax dengan ROE, semakin naik Tax maka semakin turun ROE.

Jadi berdasarkan hasil pengujian pada Tabel 4.9 tersebut diatas, dari 4 (empat) variabel independen yang diuji yaitu diperoleh hasil thitung masing-masing COLF (3.199), OHC (2.906), Risk (3.606), dan Tax (1.092), kemudian tabel dapat diperoleh dengan pengujian 2 sisi (signifikansi 0,025$)$ dan dengan derajat kebebasan (df) n-k-1 atau 10-4-1 = 5, maka diperoleh hasil tabel (2.571).

Pengujian variabel COLF dengan thitung (3.199) $>$ ttabel (2.571) maka secara parsial variabel COLF memiliki pengaruh yang signifikan terhadap ROE pada KSP. Madani NTB.

Pengujian variabel $\mathrm{OHC}$ dengan thitung (2.906) $>$ tabel (2.571) maka secara parsial variabel AKI memiliki pengaruh yang signifikan terhadap ROE pada KSP. Madani NTB.

Pengujian variabel Risk dengan thitung (3.606) $>$ tabel (2.571) maka secara parsial variabel Risk memiliki pengaruh yang signifikan terhadap ROE pada KSP. Madani NTB.

Pengujian variabel Tax dengan thitung $(1.092)<t_{\text {tabel }}(2.571)$ maka secara parsial variabel Taxtidak memiliki pengaruh yang signifikan terhadap ROE pada KSP. Madani NTB.

Hal ini berarti variabel Cost of Loanable Fund, Overhead Cost, Risk Cost, dan Tax Rate tidak seluruhnya secara parsial memiliki pengaruh yang signifikan terhadap Return on Equity pada KSP. Madani NTB, disebabkan oleh 1 (satu) variabel Tax Rate secara parsial tidak memiliki pengaruh signifikan terhadap variabel Return on Equity $(\mathrm{Y})$.

\section{Uji Simultan (Uji F)}

Pengujian hipotesis dengan Uji F dilakukan dengan bantuan program SPSS, adapun hasilnya seperti pada Tabel 4.10 di bawah ini. Dari uji $F$ diperoleh tingkat signifikansi sebesar 0.023 yang lebih kecil dari $5 \%$. Dengan menggunakan tingkat keyakinan $95 \%, a=5 \%$, df 1 (jumlah variabel -1$)=4$ dan df $2(10-4-1)=5$, maka diperoleh hasil $F_{\text {tabel }}(5.192)$. Dengan demikian $F_{\text {hitung }}$ (7.774) lebih besar dari Ftabel (5.192), artinya bahwa pada derajat tingkat kepercayaan $95 \%$ atau derajat kesalahan $5 \%$ seluruh variabel independen (Cost of Loanable Fund, Overhead Cost, Risk Cost, dan Tax Rate) secara bersama-sama memberikan pengaruh yang signifikan terhadap variabel Return on Equity $(\mathrm{Y})$. 
Tabel 4.10

Hasil Uji F : Anovab

ANOVA ${ }^{b}$

\begin{tabular}{|ll|r|r|r|r|r|}
\hline \multicolumn{2}{|l|}{ Model } & \multicolumn{1}{|c|}{$\begin{array}{c}\text { Sum of } \\
\text { Squares }\end{array}$} & \multicolumn{1}{c|}{$\mathrm{df}$} & $\begin{array}{c}\text { Mean } \\
\text { Square }\end{array}$ & $\mathrm{F}$ & Sig. \\
\hline 1 & Regression & 54.025 & 4 & 13.506 & 7.774 & $.023^{\mathrm{a}}$ \\
& Residual & 8.687 & 5 & 1.737 & & \\
& Total & 62.712 & 9 & & & \\
\hline
\end{tabular}

a. Predictors: (Constant), TAX, COLF, RISK, OHC

b. Dependent Variable: ROE

Sumber : Hasil output program SPSS

Disamping itu variabel Risk Cost $\left(\mathrm{X}_{3}\right)$ mempunyai pengaruh yang paling dominan terhadap Return on Equity pada KSP. Madani NTB, dengan hasil thitung sebesar 3.606

Nilai $R$ square sebesar 0.861 seperti tampak pada Tabel 4.11 menunjukkan bahwa kemampuan variabel $\operatorname{COLF}\left(\mathrm{X}_{1}\right), \operatorname{OHC}\left(\mathrm{X}_{2}\right), \operatorname{RISK}\left(\mathrm{X}_{3 .}\right)$, dan $\operatorname{TAX}\left(\mathrm{X}_{4}\right)$ dalam menjelaskan Return on Equity pada KSP. Madani NTB adalah sebesar $86,10 \%$ sedangkan sisanya $13,90 \%$ dijelaskan oleh variabel lain, selain variabel COLF, OHC, RISK, dan TAX $\left(\mathrm{X}_{4}\right)$.

Tabel 4.11

Hasil Uji F : Model Sumamary ${ }^{b}$

Model Summaryb

\begin{tabular}{|l|c|r|r|c|}
\hline Model & $\mathrm{R}$ & $\mathrm{R}$ Square & $\begin{array}{c}\text { Adjusted } \mathrm{R} \\
\text { Square }\end{array}$ & $\begin{array}{c}\text { Std. Error of the } \\
\text { Estimate }\end{array}$ \\
\hline 1 & $.928^{\mathrm{a}}$ & .861 & .751 & 1.31808 \\
\hline
\end{tabular}

a. Predictors: (Constant), TAX, COLF, RISK, OHC

b. Dependent Variable: ROE

Sumber : Hasil output program SPSS

Sedangkan nilai R (Koefesaien Korelasi ) sebesar 0.928 menunjukan bahwa terdapat hubungan yang sangat kuat antara variabel $\operatorname{COLF}\left(\mathrm{X}_{1}\right), \mathrm{OHC}$ $\left(\mathrm{X}_{2 .}\right)$, $\operatorname{RISK}\left(\mathrm{X}_{3 .}\right)$, dan $\operatorname{TAX}\left(\mathrm{X}_{4}\right)$ dengan Return on Equity $(\mathrm{Y})$.

\section{Pembahasan}

Hasil penelitian pengaruh faktor-faktor Base Lending Rate terhadap Return on Equity pada KSP.Madani NTB, tidak seluruhnya secara parsial memiliki pengaruh yang signifikan terhadap Return on Equity pada KSP. Madani NTB, disebabkan oleh 1 (satu) variabel Tax Rate secara parsial tidak memiliki pengaruh signifikan terhadap variabel Return on Equity $(\mathrm{Y})$. Disamping itu variabel Risk Cost $\left(\mathrm{X}_{3}\right)$ mempunyai pengaruh yang paling dominan terhadap Return on Equity pada KSP. Madani NTB, dengan hasil thitung sebesar 3.606 
Nilai $\mathrm{R}$ square sebesar 0.861 menunjukkan bahwa kemampuan variabel $\operatorname{COLF}\left(\mathrm{X}_{1}\right)$, OHC $\left(\mathrm{X}_{2}\right)$, RISK $\left(\mathrm{X}_{3}\right)$, dan TAX $\left(\mathrm{X}_{4}\right)$ dalam menjelaskan Return on Equity pada KSP. Madani NTB adalah sebesar $86,10 \%$ sedangkan sisanya $13,90 \%$ dijelaskan oleh variabel lain, selain variabel COLF, OHC, RISK, dan $\operatorname{TAX}\left(\mathrm{X}_{4}\right)$.

Hasil penelitian ini terjadi hubungan yang negatif antara Return on Equity dengan Cost of Loanable Fund, Risk Cost dan Tax Rate, dimana pada saat COLF, Risk dan Tax naik, maka ROE akan mengalami penurunan, yang artinya setiap kenaikan COLF, Risk dan Tax akan diikuti oleh penurunan ROE dan terjadi hubungan yang positif antara Return on Equity dengan Overhead Cost, dimana pada saat $\mathrm{OHC}$ meningkat juga diikuti peningkatan ROE.

Naiknya rasio COLF akan diketahui seberapa besar biaya dana yang ditempatkan untuk memperoleh pendapatan, apabila COLF tinggi akan menunjukkan kemampuan koperasi untuk memperoleh dana, dimana biaya bunga atas sumber dana yang diperoleh cukup tinggi sehingga akan berpengaruh terhadap kemampuan dalam penempatan dana dalam bentuk kredit dan akhirnya akan mempengaruhi tingkat keuntungan atau sebaliknya.

Risk Cost dapat memberikan informasi seberapa berhasilnya koperasi mampu menekan kredit bermasalah, apabila rasio ini meningkat, maka hal ini menunjukan bahwa koperasi tersebut belum mampu menekan kredit bermasalahnya, sehingga akan mengakibatkan meningkatnya biaya yang dikeluarkan untuk membentuk cadangan penghapusan kredit bermasalah, meningkatnya biaya cadangan pengahapusan akan mengakibatkan penurunan tingkat keuntungan yang diperoleh koperasi.

Khusus yang berkaitan dengan Tax Rate sangat dipengaruhi oleh kebijakan dari pemerintah, semakin tinggi tingkat pajak yang ditetapkan oleh pemerintah akan mempengaruhi tingkat bunga kredit yang dibebankan kepada debiturnya, akibatnya akan menurunkan pembagian SHU yang akan diterima oleh anggota. Dalam hal ini Tax Rate tidak memiliki pengaruh yang signifikan, karena tingkat pajak yang harus dibayar oleh koperasi tergantung dari kebijakan pemerintah, koperasi hanya bisa mengikutinya.

Hal yang menarik dari hasil penelitian ini, dimana terjadi hubungan yang positif antara Return on Equity dengan Overhead Cost, dimana pada saat OHC meningkat juga diikuti peningkatan ROE. Overhead Cost merupakan biaya yang dikeluarkan dalam proses penghimpunan dana, semakin tinggi OHC akan mengakibatkan meningkatnya tingkat bunga kredit, sehingga bunga kredit yang dibebankan kepada debitur juga meningkat, sehingga akan menurunkan tingkat keuntungan. Namun dalam hal ini tidak secara otomatis akan berakibat pada penurunan tingkat keuntungan dan bahkan sebaliknya akan bisa meningkatkan tingkat keuntungan, hal ini disebabkan oleh kemampuan koperasi dalam mengoptimalkan sumder daya yang dimiliki koperasi, terutama sumber 
daya manusia (SDM/karyawan). Optimalisasi pelayanan ditingkatkan dengan meningkatkan efesiensi pelayanan, salah satu komponen $\mathrm{OHC}$ adalah biaya karyawan, walaupun biaya karyawan mengalami peningkatan tetapi juga diikuti peningkatan volume pemberian pinjaman yang cukup signifikan maka akan meningkatkan jumlah kredit yang diberikan, kredit meningkat akan diikuti pendapatan bunga juga meningkat dan akan meningkatkan tingkat keuntungan.

\section{Kesimpulan}

\section{KESIMPULAN DAN SARAN}

Berdasarkan hasil penelitian dan pembahasan yang telah dilakukan mengenai pengaruh faktor-faktor Base Lending Rate (Cost of Loanable Fund/COLF, Overhead Cost/OHC, Risk Cost, Tax Rate) terhadap Return on Equity/ROE, dapat diambil beberapa kesimpulan sebagai berikut :

1. Berdasarkan hasil pengujian bahwa tidak seluruh variabel cost of Loanable Fund/COLF, Overhead Cost/OHC, Risk Cost, Tax Rate secara parsial memiliki pengaruh yang signifikan terhadap Return on Equity/ROE pada KSP.Madani NTB. Yang berpengaruh signifikan terhadap variabel Return on Equity/ROE adalah variabel cost of Loanable Fund/COLF, Overhead Cost/OHC, dan Risk Costdan yang tidak berpengaruh signifikan terhadap Return on Equity/ROE adalah variabel Tax Rate pada KSP.Madani NTB.

2. Bedasarkan hasil pengujian bahwa variabel cost of Loanable Fund/COLF, Overhead Cost/OHC, Risk Cost, Tax Rate secara simultan memiliki pengaruh yang signifikan terhadap Return on Equity/ROE pada KSP.Madani NTB.

3. Dari hasil pengujian bahwa Risk Cost memiliki pengaruh yang paling dominan terhadap Return on Equity/ROE pada KSP.Madani NTB.

4. Berdasarkan nilai R (Koefesaien Korelasi ) sebesar 0.928 menunjukan bahwa terdapat hubungan yang sangat kuat antara variabel $\operatorname{COLF}\left(X_{1}\right)$, $\mathrm{OHC}\left(\mathrm{X}_{2 .}\right)$, RISK $\left(\mathrm{X}_{3 .}\right)$, dan TAX $\left(\mathrm{X}_{4}\right)$ dengan Return on Equity $(\mathrm{Y})$.

\section{Saran}

Setelah menyimpulkan hasil dari penelitian ini, maka penulis dapat memberikan saran-saran yang bisa dijadikan bahan informasi sebagai landasan dalam melaksanakan kegiatan usaha dalam pengambilan kebijakan dan keputusan oleh KSP. Madani NTB, sebagai berikut :

1. Diharapkan KSP.Madani NTB dalam mencari sumber dana mengupayakan peningkatan sumber dana yang murah, yang merperhatikan struktur dana yang ideal antara sumber dana dalam bentuk simpanan berjangka dengan tabungan. Struktur dana yang ideal akan mempengaruhi Cost of Loanable Funds.

2. Pengurus hendaknya memperhatikan kualitas aktiva produktif yang dimiliki koperasi, terutama kualitas kredit yang diberikan. Koperasi harus 
berupaya menekan peningkatan kredit bermasalahnya, menekan kredit bermasalah akan mengurangi Risk Cost.

\section{DAFTAR PUSTAKA}

Gujarati, D. (1999), Basic Econometrics, Edisi Bahasa Indonesia, Jakarta : Erlangga.

Kuncoro, M. (2007), Metode Kuantitatif Teori dan Aplikasi Untuk Bisnis dan Ekonomi, Edisi Ketiga, Yogyakarta : Unit Penerbit dan Percetakan (UPP) STIM YKPN.

Kasmir, (2010), Bank dan Lembaga Keuangan, Edisi Revisi, Jakarta : PT.Rajagrafindo Persada.

Muljono, Djoko (2012), Buku Pintar Strategi Bisnis Koperasi Simpan Pinjam, Yogyakarta : CV. Andi Offset.

Sunyoto, Danang, drs.,S.H.,M.M. (2009), Analisis Regresi dan Uji Hipotesis, Cetakan Pertama, Yogyakarta : MedPress.

Taswan, Dr.(Cand.), S.E.,M.Si. (2010), Manajemen Perbankan Konsep, Teknik \& Aplikasi, Edisi II, Yogyakarta : UPP STIM YKPN Yogyakarta. .(1992), Undang-Undang Republik Indonesia Nomor 25 Tahun 1992, Tentang Perkoperasian, Jakarta : Menteri Sekretaris Negara Republik Indonesia, Lembaran Negara Republik Indonesia Tahun 1992 Nomor 116 .(2016), Peraturan Deputi Menteri Koperasi dan Usaha Kecil dan Menengah Republik Indonesia Nomor 06/Per/Dep.6/IV/2016 tanggal 19 April 2016 Tentang Pedoman Penilaian Kesehatan Koperasi Simpan Pinjam dan Unit Simpan Pinjam. .(2017), Peraturan Menteri Koperasi dan Usaha Kecil dan Menengah Republik Indonesia Nomor 02/Per/M.KUKM/II/2017 tanggal 9 Februari 2017 Tentang Perubahan Atas Peraturan Menteri Koperasi dan Usaha Kecil dan Menengah Nomor 15/Per/M.KUKM/IX/2015 Tentang Usaha Simpan Pinjam Oleh Koperasi. 